\title{
ADENITE SEBÁCEA EM UM CANINO: RELATO DE CASO
}

\author{
(Sebaceus adenitis in a dog: case report)
}

Karim Cristhine Pase Montagnini, Juliana Das Chagas Goulart, Arthur Colombari Cheng, Joana Cristina Smaha De Jesus Lima, Carolina Fontana, Larissa Donat Almagro, Solimar Dutra da Silveira, Aline De Marco Viott

Universidade Federal do Paraná, Palotina, Paraná, Brasil.

*Correspondência: alinedemarco@yahoo.com.br

RESUMO: A adenite sebácea é uma afecção cutânea de etiologia incerta, que se manifesta de forma incomum na espécie canina e raramente na espécie felina. Em cães, os jovens adultos são os mais afetados e não há predileção por sexo. Raças como Standard Poodle, Samoieda, Akita e Vizsla são mais acometidas, além de que, essa condição já foi relatada em raças mestiças. As regiões mais acometidas são a região dorsal do tronco, temporal da face e as pinas e, geralmente as lesões caracterizam-se por escamas aderentes, que formam aglomerados foliculares e frondes, pelos secos, opacos e quebradiços; também pode afetar a cauda, resultando alopecia marcante e escamas aderentes (cauda de rato) (GROSS et al., 2009). Diante disso, relata-se um caso de adenite sebácea em um canino, diagnosticado pelo Laboratório de Patologia Veterinária (LPV) da Universidade Federal do Paraná (UFPR), Setor Palotina. Um canino, da raça Pitbull, fêmea, seis anos de idade com $26,9 \mathrm{Kg}$, foi atendido no Hospital Veterinário da UFPR apresentando áreas alopécicas em região periocular, peribucal, podal e pina de orelha bilateral, com presença de descamação e rarefação pilosa em região de cauda, além de onicogrifose e linfadenomegalia generalizada. Realizou-se exames complementares, como a citologia aspirativa dos linfonodos poplíteos obtendo resultado compatível de hiperplasia linfoide; raspado cutâneo, o qual não foi visualizado ácaros; punção de medula óssea, sem alterações significativas e Reação em Cadeia pela Polimerase (PCR) negativa para Leishmaniose. Optou-se então pela exérese de fragmentos das áreas acometidas, as quais posteriormente foram enviadas para o LPV da UFPR. Na microscopia, em todos os cortes, observou-se a epiderme com presença de hiperqueratose ortoqueratótica multifocal moderada e na derme superficial e profunda, havia presença de infiltrado inflamatório multifocal moderado, composto por linfócitos, macrófagos, mastócitos, plasmócitos e células de Mott, principalmente ao redor dos anexos (adenite), além da ausência de glândulas sebáceas. As alterações histopatológicas visualizadas associadas ao quadro clínico do animal corroboraram com o diagnóstico de adenite sebácea. Segundo Gross et al. (2009) os diagnósticos diferenciais, neste caso, devem incluir seborreia primária e dermatite seborreica, ictiose, dermatose responsiva a vitamina $\mathrm{A}$, demodicose e dermatofitose generalizada. Desta forma, ressalta-se a importância do exame histopatológico como ferramenta de diagnóstico em casos de alterações cutâneas, possibilitando o tratamento adequado ao paciente.

Palavras-chave: diagnóstico; glândula sebácea; histopatológico

\section{Referência}

GROSS, L. T.; IHRKE, P. J.; WALDER, E. J.; AFFOLTER, V. K. Doenças de pele do cão e do gato: Diagnóstico Clínico e Histopatológico. $2^{\text {a }}$ ed. São Paulo: Roca, 2009. 